\title{
A film documenting the international SCENARIO FORUM CONFERENCE 2017
}

\section{Patricia Klich \& Maciek Klich}

\begin{abstract}
This clip will evoke and inspire: for those who were at the conference Performative Spaces in Language, Literature and Culture Education (University College Cork, May 25 - 28), it will no doubt bring back the memories, the connections, the 'aha' moments. For those who couldn't make it, it is a great opportunity to catch up on key issues of the conference, especially as Manfred Schewe's opening interview offers a rationale for performative language teaching. Eva Göksel's enchanting voice features throughout as the soundtrack of the film, a melodic thread that joins different voices together, in her live interpretation of the Irish Raggle Taggle Gypsy ballad.
\end{abstract}

Thefilm can be viewed on YouTubeat: https://www.youtube.com/watch?v=_J5uFayugUQ\&feature =yo 